\title{
Pengaruh Lama Fermentasi Terhadap Karakteristik Fermented Rice Drink Sebagai Minuman Probiotik Dengan Isolat Lactobacillus sp. F213
}

\author{
Effect of Fermentation Time on the Characteristics of Fermented Rice Drink as Probiotic Drink with \\ Lactobacillus sp. F213 Isolates
}

\author{
Gusti Putu Adi Wira Kusuma*, Komang Ayu Nocianitri, I Desak Putu Kartika Pratiwi \\ Program Studi Ilmu dan Teknologi Pangan, Fakultas Teknologi Pertanian, \\ Universitas Udayana, Jl. Raya Kampus Unud, Jimbaran, Kuta Selatan, Badung-Bali \\ *Penulis Korespondensi: Gusti Putu Adi Wira K, Email: adiwira09@gmail.com
}

\begin{abstract}
This research aims to identify the effect of fermentation time on the characteristics of fermented rice drinks and to identify the proper fermentation time to produce fermented rice drink with the best characteristics. Fermentation of fermented rice drink used the Lactobacillus sp. F213 isolates. This research used a randomized block design (RBD) with fermentation time as treatment, namely 18, 20, 22, 24, and 26 hours. Each treatment was repeated 3 times resulting in 15 experimental units. The data were analyzed by analysis of variance (ANOVA) and if the treatment affected the variable, then proceed with the Duncan test. The results showed that the fermentation time had a significant effect on total LAB, total sugar, total acidity, $\mathrm{pH}$, and sour taste score of fermented rice drink. The 22 hours fermentation time treatment produced the best characteristics of fermented rice drink, with the following criteria: total LAB 13,26 Log CFU/ml, total sugar 22, $35 \%$, total acidity $1,71 \%, \mathrm{pH} 3,99$, the color and taste that sweet and rather sour were preferred, the aroma was rather preferred, and overall acceptance was preferred.
\end{abstract}

Keywords: probiotic, fermented rice drink, Lactobacillus sp. F213.

\section{PENDAHULUAN}

Fermented rice drink merupakan sari hasil fermentasi nasi menggunakan kultur murni kapang Amylomyces rouxii. Kapang A. rouxii merupakan mikroorganisme yang mampu menghasilkan enzim amiloglukosidase yang dapat memecah pati menjadi gula sederhana seperti glukosa selama proses fermentasi (Nout, 2007) sehingga fermented rice drink yang dihasilkan memiliki rasa yang manis. Menurut penelitian Wongkhalaung et al. (2000), menunjukkan bahwa aktivitas enzim amiloglukosidase selama proses fermentasi nasi dapat meningkatkan kandungan glukosa pada nasi fermentasi hingga $23,8 \%$.
Fermented rice drink dengan kandungan glukosa yang tinggi dapat menjadi substrat yang baik untuk bakteri asam laktat probiotik dalam melakukan fermentasi sehingga dapat dihasilkan minuman fermented rice drink yang mengandung probiotik sebagai upaya pengembangan pangan fungsional. Probiotik adalah mikroorganisme hidup yang apabila diberikan dalam jumlah cukup dapat memberi efek menyehatkan bagi tubuh dengan cara memperbaiki komposisi mikrobia usus (Susanti et al., 2007). Bakteri yang umum digunakan sebagai strain probiotik dalam pangan adalah strain bakteri Lactobacillus dan Bifidobacterium. Kedua jenis 
bakteri tersebut dikenal memiliki ketahanan yang baik di dalam saluran pencernaan manusia.

Lactobacillus sp. F213 (LbF213) merupakan bakteri asam laktat yang diisolasi dari feses bayi sehat yang memiliki potensi sebagai probiotik sebab memiliki ketahanan yang baik pada kondisi pencernaan secara in vitro. Menurut Sujaya et al. (2015) penelitian secara in vitro dari aspek fungsionalnya menunjukkan bahwa Lactobacillus sp. F213 memiliki kemampuan melekat pada epitel saluran pencernaan mencit untuk mencegah diare dan diduga dapat menstimulasi sistem imun. Selain itu Lactobacillus sp. F213 juga mampu menghidrolisis garam empedu dan berpotensi menurunkan kolesterol darah. Berdasarkan hal tersebut, untuk memudahkan konsumsi Lactobacillus sp. F213 dan menghasilkan media pembawa probiotik yang dapat dikonsumsi, maka Lactobacillus sp. F213 dapat ditambahkan ke dalam fermented rice drink.

Fermentasi merupakan suatu proses perubahan kimia pada suatu substrat organik melalui aktivitas enzim yang dihasilkan oleh mikroorganisme (Suprihatin, 2010). Mikroba yang umumnya terlibat dalam fermentasi pangan adalah bakteri, khamir dan kapang. Prinsip dasar fermentasi adalah mengaktifkan aktivitas mikroba tertentu agar dapat merubah sifat bahan sehingga dihasilkan produk fermentasi yang bermanfaat. Beberapa faktor yang mempengaruhi fermentasi antara lain mikroorganisme, substrat (medium), pH (keasaman), suhu, oksigen, dan aktivitas air (Afrianti, 2013). Menurut Buckle et al. (1985) selain zat gizi, suhu, air, pH dan oksigen, fermentasi juga dipengaruhi oleh waktu. Waktu fermentasi merupakan variabel yang berkaitan dengan fase pertumbuhan mikroba selama proses fermentasi berlangsung sehingga akan berpengaruh terhadap hasil fermentasi. Penelitian sebelumnya menunjukkan bahwa lama fermentasi mempengaruhi karateristik minuman fermentasi asam laktat dari beras. Berdasarkan penelitian Wongkhalaung et al., (2000), menunjukkan bahwa waktu fermentasi pada rice milk menggunakan bakteri Lactobacillus acidophilus IFRPD 2013 dan Lactobacillus casei subsp. rhamnosus IFRPD 2020 selama 24 jam pada suhu $37^{\circ} \mathrm{C}$ menghasilkan produk rice yoghurt terbaik dengan kandungan asam laktat $0,8 \%$, total BAL $1 \mathrm{x}$ $10^{8} \mathrm{CFU} / \mathrm{g}$, dan $\mathrm{pH}$ 3,58. Menurut Yunus et al. (2015) waktu fermentasi asam laktat yang terlalu singkat akan menyebabkan pertumbuhan bakteri asam laktat tidak optimal dan jumlah populasinya kurang untuk dikategorikan sebagai probiotik, sedangkan waktu fermentasi yang terlalu lama akan menghasilkan rasa yang terlalu asam pada produk dan juga menyebabkan penurunan jumlah populasi bakteri asam laktat akibat habisnya nutrisi pada substrat dan terakumulasinya metabolit yang bersifat toksik seperti etanol yang dihasilkan oleh bakteri asam laktat heterofermentatif.

Berdasarkan latar belakang tersebut, perlu dilakukan penelitian untuk mengetahui pengaruh lama fermentasi terhadap minuman fermented rice drink dan untuk mengetahui lama fermentasi yang dapat menghasilkan karakteristik minuman fermented rice drink terbaik.

\section{METODE PENELITIAN}

\section{Tempat dan Waktu Penelitian}

Penelitian ini dilaksanakan di UPT. Laboratorium Terpadu Biosains dan Bioteknologi Universitas Udayana, Laboratorium Biokimia dan Nutrisi Fakultas Teknologi Pertanian Universitas 
Udayana, serta Laboratorium Rekayasa Proses dan Pengendalian Mutu Fakultas Teknologi Pertanian Universitas Udayana. Penelitian ini dilaksanakan dari bulan Juni sampai Agustus 2019.

\section{Bahan dan Alat}

Bahan yang digunakan dalam penelitian ini adalah isolat Lactobacillus sp. F213 (koleksi UPT Laboratorium Terpadu Biosains dan Bioteknologi Universitas Udayana), Amylomyces rouxii (koleksi UPT Laboratorium Terpadu Biosains dan Bioteknologi Universitas Udayana), beras varietas C4 (Putri Sejati), media MRSB (deMann Rogossa Sharpe Broth) (Oxoid), media MRSA (deMann Rogosa Sharpe Agar) (Oxoid), Potato Dextrose Agar (Merch), air, alkohol 96\%, aquades, $\mathrm{NaCl}$ 0,85\%, gliserol, alumunium foil, tissue, kertas saring, kristal violet, safranin, larutan lugol, larutan $\mathrm{H}_{2} \mathrm{O}_{2}, \mathrm{HCl} 4 \mathrm{~N}$, $\mathrm{NaOH} 0,1 \mathrm{~N}$, pereaksi anthrone (Merck), $\mathrm{H}_{2} \mathrm{SO}_{4}$ pekat, phenolphtalein $1 \%$, glukosa standar, larutan buffer $\mathrm{pH}$ 4, 7 dan 10, Metanol $95 \%$.

Peralatan yang digunakan dalam penelitian ini adalah panci kukus, kain saring, baskom, kompor, botol kaca $100 \mathrm{ml}$, cawan petri (Petriq), kaca objek, tabung reaksi (Pyrex), tabung eppendorf, tabung durham, batang bengkok, jarum ose, bunsen, vortex (Labnet), freezer (GEA), inkubator (Memmert), water bath (NVC Thermologic), laminar air flow (JSR JSCB-900SB), spektrofotometer (Thermo Scientific Evolution 201), alat titrasi, pH-meter (Martini Instrument MI 105), timbangan analitik (Shimadzu AUX 220), mikroskop, pipet mikro (Genex Beta), tip kuning ukuran $100 \mu \mathrm{l}$, tip biru ukuran $1 \mathrm{ml}$, pipet tetes, pipet volume, labu ukur, erlenmeyer (Pyrex), autoklaf, magnetik stirer (Fisher Scientific), dan termometer.

\section{Rancangan Percobaan}

Rancangan percobaan yang digunakan pada penelitian ini adalah rancangan acak kelompok (RAK) dengan satu faktor yakni lama waktu fermentasi yang terdiri dari 5 taraf sebagai berikut :

$\mathrm{T} 1$ = lama fermentasi $18 \mathrm{jam}$,

$\mathrm{T} 2$ = lama fermentasi $20 \mathrm{jam}$,

$\mathrm{T} 3$ = lama fermentasi 22 jam,

$\mathrm{T} 4$ = lama fermentasi 24 jam,

T5 = lama fermentasi 26 jam.

Masing-masing perlakuan diulang sebanyak 3 kali sehingga diperoleh 15 unit percobaan.

\section{Penyegaran dan Konfirmasi Isolat Lactobacillus sp. F213}

Bakteri Lactobacillus sp. F213 dilakukan penyegaran dengan cara diambil $100 \mu \mathrm{L}$ stok isolat yang disimpan dalam gliserol $30 \%$ pada suhu $-20^{\circ} \mathrm{C}$ dan diinokulasi pada $5 \mathrm{ml}$ media MRS Broth dan diinkubasi selama 24 jam dengan suhu $37^{\circ} \mathrm{C}$. Hasil positif ditunjukkan dengan munculnya kekeruhan pada media. Setelah penyegaran, dilakukan konfirmasi isolat melalui uji katalase, pewarnaan gram dan uji gas. Uji katalase dilakukan dengan dibuat tetesan isolat pada gelas objek, kemudian ditetesi dengan dua tetes larutan $\mathrm{H}_{2} \mathrm{O}_{2}$, dan diamati gelembung yang timbul (Suryani et al., 2010a). Pewarnaan gram dilakukan dengan meneteskan isolat pada gelas objek kemudian difiksasi di atas bunsen dan diwarnai dengan kristal violet selama 1 menit, kemudian ditetesi dengan larutan lugol selama 1 menit. Selanjutnya gelas objek ditetesi aseton alkohol selama 1 menit dan terakhir diwarnai dengan pewarna safranin selama 5 detik. Sel bakteri yang telah diwarnai, dikeringkan dan diamati dibawah mikroskop (Suryani et al., 2010b). Uji gas dilakukan 
dengan metode hot loop, dengan cara memasukkan jarum ose panas ke dalam suspensi biakan BAL (Suryani et al., 2010c).

\section{Penyegaran dan Konfirmasi Isolat Amylomyces rouxii}

Kapang Amylomyces rouxii dilakukan penyegaran dengan cara memotong isolat Amylomyces rouxii pada media PDA yang disimpan pada suhu $-20^{\circ} \mathrm{C}$, kemudian diinokulasi pada media PDA yang baru. Selanjutnya diinkubasi selama 4 hari dengan suhu $37^{\circ} \mathrm{C}$. Hasil positif ditunjukkan dengan munculnya miselia berupa serabut berwarna putih pada media PDA. Uji konfirmasi kapang Amylomyces rouxii dilakukan dengan melihat bentuk miselia yang tumbuh dengan mikroskop, dimana miselia kapang Amylomyces rouxii berwarna putih dan memiliki klamidospora.

\section{Pembuatan Starter Fermented Rice Drink}

Pembuatan fermented rice drink melalui beberapa proses yaitu: Persiapan starter fermented rice drink yaitu dari kapang Amylomyces rouxii. Kapang Amylomyces rouxii diinokulasi pada media PDA dengan metode sebar dan dinkubasi selama 4 hari pada suhu $37{ }^{\circ} \mathrm{C}$. Uji konfirmasi kapang Amylomyces rouxii dilakukan dengan melihat bentuk miselia yang tumbuh dengan mikroskop, dimana miselia kapang Amylomyces rouxii berwarna puth dan memiliki klamidospora. Selanjutnya, beras yang akan digunakan dicuci dan dibersihkan. Selanjutnya beras direndam menggunakan air dengan perbandingan 1:1 pada suhu kamar selama 30 menit, kemudian ditiriskan. Beras dikukus selama 30 menit dan selanjutnya diaron dengan cara menambahkan air panas dengan perbandingan beras : air yaitu $3: 2$. Proses pengaron dilakukan selama 15 menit dan dikukus kembali selama 30 menit. Berat nasi yang diperoleh ditimbang dan didinginkan. Setelah dingin, nasi diinokulasi dengan miselium kapang Amylomyces rouxii dengan cara memotong agar dengan spatula (4 x $4 \mathrm{~mm}$ ). Setiap 100 gr nasi dinokulasi dengan 5 buah potongan agar yang megandung miselium dan spora Amylomyces rouxii. Selanjutnya diinkubasi selama 4 hari, pada suhu 32 ${ }^{\circ} \mathrm{C}$. Nasi hasil fermentasi siap digunakan sebagai starter fermented rice drink.

\section{Pembuatan Minuman Fermented Rice Drink}

Pembuatan fermented rice drink melalui beberapa proses yaitu: Beras yang akan digunakan dicuci dan dibersihkan. Selanjutnya beras direndam menggunakan air dengan perbandingan $1: 1$ pada suhu kamar selama 30 menit, kemudian ditiriskan. Selanjutnya, beras dikukus selama 30 menit dan diaron dengan cara menambahkan air panas dengan perbandingan beras : air yaitu $3: 2$. Proses pengaronnya dilakukan selama 15 menit. Selanjutnya beras aron dikukus kembali selama 15 menit sehingga menjadi nasi. Setelah dingin, nasi diinokulasi dengan $5 \%$ (berat) starter fermented rice drink dan 5\% gula. Selanjutnya diinkubasi selama 4 hari, pada suhu $37{ }^{\circ} \mathrm{C}$. Nasi hasil fermentasi selanjutnya ditambahkan air dengan perbandingan $1: 1$. Kemudian diperas dengan bantuan kain saring dan didapatkan cairan fermented rice drink. Fermented rice drink sebanyak $100 \mathrm{ml}$ dikemas ke dalam botol jar steril, kemudian dipasteurisasi dengan suhu $80{ }^{\circ} \mathrm{C}$ selama 15 menit. 
Inokulasi Lactobacillus sp. F213 Pada Fermented Rice Drink

Stok kultur Lactobacillus sp. F213 diambil sebanyak $100 \mu \mathrm{l}$ dalam gliserol dan dimasukkan ke dalam $5 \mathrm{ml}$ media MRSB, lalu diinkubasi selama 24 jam pada $37^{\circ} \mathrm{C}$. Setelah inkubasi, media tersebut diamati, hasil positif ditunjukan dengan kekeruhan pada media, tabung reaksi tersebut kemudian divortex dan diambil sebanyak $1 \mathrm{ml}$, kemudian dipindahkan ke dalam tabung eppendorf untuk disentrifugasi pada kecepatan $5000 \mathrm{rpm}$ selama 10 menit.

Setelah disentrifugasi, akan terbentuk endapan kultur mikroba pada dasar tabung eppendorf. MRSB di atas endapan kultur tersebut dibuang, sedangkan sel yang tertinggal dicuci sebanyak 3 kali. Pencucian sel dilakukan dengan cara menambahkan larutan saline ke dalam tabung eppendorf berisi endapan kultur Lactobacillus sp. F213 lalu divorteks, selanjutnya eppendorf disentrifugasi pada kecepatan $5000 \mathrm{rpm}$ selama 10 menit, dan membuang supernatan yang terbentuk setelah proses sentrifugasi.

Larutan saline sisa dari pencucian terakhir dibuang, kemudian diambil sebanyak $1 \mathrm{ml}$ fermented rice drink dan dimasukkan ke dalam tabung eppendorf. Tabung eppendorf tersebut divortex dan kultur dalam eppendorf dimasukkan ke dalam fermented rice drink yang telah dipasteurisasi, kemudian dikocok. Selanjutnya fermented rice drink diinkubasi sesuai perlakuan lama fermentasi yaitu T1 (18 jam), T2 (20 jam), T3 (22 jam), T4 (24 jam), dan T5 (26 jam) pada suhu $37^{\circ} \mathrm{C}$.

\section{Variabel yang diamati}

Variabel yang diamati pada penelitian ini adalah total BAL (Fardiaz, 1993), total asam (terhitung asam laktat) (Ruck, 1963), pH (Bouton dan Haris, 1972), total gula (Andarwulan et al., 2011), dan evaluasi sensoris (Soekarto, 1985) yang meliputi uji hedonik warna, aroma, rasa, dan penerimaan keseluruhan, serta uji skoring rasa manis dan rasa asam.

\section{Analisis Data}

Data yang diperoleh dari hasil pengamatan akan dianalisis secara statistik menggunakan Analysis of Variance (ANOVA). Jika terdapat pengaruh antara perlakuan (berbeda nyata) maka dilanjutkan dengan uji Duncan New Multiple Range Test (DNMRT) pada taraf 5\% (Gomez dan Gomez, 1995).

\section{HASIL DAN PEMBAHASAN}

Total BAL

Hasil sidik ragam menunjukkan bahwa perlakuan lama fermentasi berpengaruh nyata $(\mathrm{P}<0,05)$ terhadap total BAL fermented rice drink. Gambar 1 menunjukkan bahwa nilai total BAL fermented rice drink berkisar antara 10,93 Log CFU/ml - 13,26 Log $\mathrm{CFU} / \mathrm{ml}$. Nilai total BAL terendah terdapat pada perlakuan lama fermentasi 18 jam (T1), sedangkan nilai total BAL tertinggi terdapat pada perlakuan lama fermentasi 22 jam (T3) yang tidak berbeda nyata dengan perlakuan lama fermentasi 24 jam (T4) dan 26 jam (T5). Gambar 1 menunjukkan bahwa selama proses fermentasi fermented rice drink terjadi kecenderungan peningkatan jumlah total BAL seiring semakin lama waktu fermentasi. 


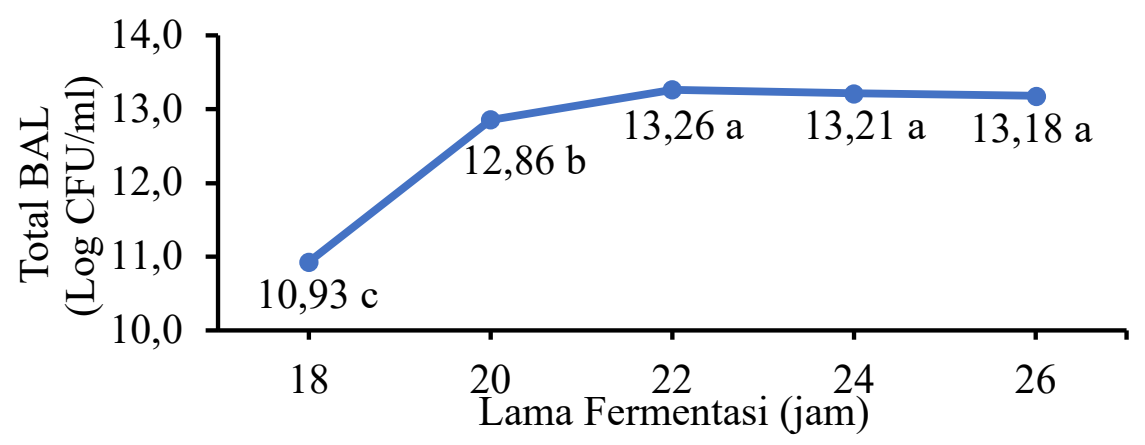

Gambar 1. Perubahan total BAL fermented rice drink selama fermentasi

Peningkatan jumlah sel bakteri asam laktat signifikan terjadi pada lama fermentasi antara $18-22$ jam, dimana total BAL meningkat dari 10,93 Log CFU/ml menjadi 13,26 Log CFU/ml. Hal tersebut membuktikan bahwa fermented rice drink merupakan media pertumbuhan yang baik bagi bakteri Lactobacillus sp. F213. Selama proses fermentasi yang terjadi, gula yang terkandung dalam fermented rice drink dimanfaat oleh bakteri Lactobacillus sp. F213 untuk melakukan metabolisme sehingga terjadi pertumbuhan sel. Menurut Yunus et al. (2015) waktu inkubasi bakteri asam laktat yang semakin lama akan memberikan kesempatan kepada bakteri asam laktat untuk memfermentasi gula menghasilkan asam laktat dan energi untuk pertumbuhan.

Berdasarkan Gambar 1, jumlah sel bakteri asam laktat pada lama fermentasi antara 22 - 26 jam tidak berbeda nyata atau relatif tetap. Hal tersebut terjadi diduga karena pada lama fermentasi antara $22-26$ jam pertumbuhan sel bakteri telah memasuki fase stasioner. Menurut Mardalena (2016) pada fase stasioner terjadi penurunan laju pertumbuhan bakteri sehingga jumlah sel yang tumbuh sama dengan jumlah sel yang mati, dimana penurunan laju pertumbuhan bakteri dikarenakan jumlah nutrien dalam media dan cadangan energi mulai berkurang. Selain itu menurut Yuliana (2008), terakumulasinya produk hasil metabolismberupa asam-asam organik seperti asam laktat, asam asetat dan asam piruvat akan menurunkan $\mathrm{pH}$ media sehingga menghambat pertumbuhan bakteri asam laktat.

Menurut Shah (2007) jumlah minimal strain probiotik yang ada dalam produk makanan adalah sebesar $10^{6} \mathrm{CFU} / \mathrm{g}$ atau $\mathrm{CFU} / \mathrm{ml}$, dimana jumlah strain probiotik yang harus dikonsumsi setiap hari sekitar $10^{8}$ $\mathrm{CFU} / \mathrm{g}$ atau $\mathrm{CFU} / \mathrm{ml}$ dengan tujuan untuk mengimbangi kemungkinan penurunan jumlah bakteri probiotik pada saat berada dalam jalur pencernaan. Fermented rice drink dengan semua perlakuan lama fermentasi pada penelitian ini telah memenuhi syarat minimal sebagai bahan pangan yang mengandung probiotik.

\section{Total Gula}

Hasil sidik ragam menunjukkan bahwa perlakuan lama fermentasi berpengaruh nyata $(\mathrm{P}<0,05)$ terhadap total gula fermented rice drink. Gambar 2 menunjukkan bahwa nilai total gula fermented rice drink berkisar antara $10,00 \%-35,12 \%$. Nilai total gula tertinggi terdapat pada perlakuan lama fermentasi 18 jam (T1), sedangkan nilai total gula terendah terdapat pada perlakuan lama fermentasi 26 jam (T5). 


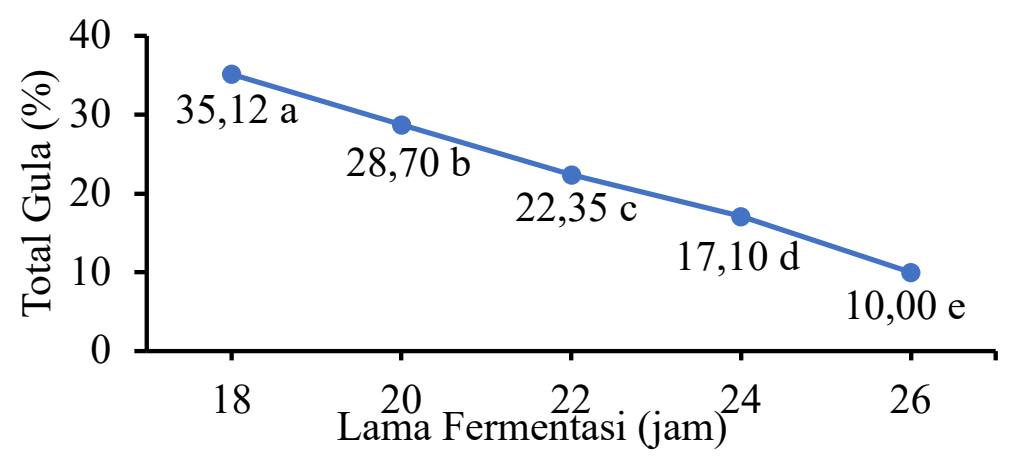

Gambar 2. Perubahan total gula fermented rice drink selama fermentasi.

Selama proses fermentasi, bakteri asam laktat merombak gula pada fermented rice drink melalui sistem metabolismenya sehingga menghasilkan energi untuk melakukan pertumbuhan. Menurut Koesoemawardani et al., (2013) gula pada media pertumbuhan akan dimanfaatkan bakteri asam laktat sebagai sumber karbon untuk aktivitas kerjanya, sehingga semakin lama fermentasi jumlah gula akan semakin menurun. Bakteri asam laktat umumnya mendapatkan energi dari glukosa, tetapi beberapa spesies juga mengunakan gula-gula seperti laktosa, sukrosa dan xilosa.

\section{Total Asam}

Hasil sidik ragam menunjukkan bahwa perlakuan lama fermentasi berpengaruh nyata $(\mathrm{P}<0,05)$ terhadap total asam fermented rice drink. Gambar 3 menunjukkan bahwa nilai total asam fermented rice drink berkisar antara 1,23\% - 1,71\%. Nilai total asam terendah terdapat pada perlakuan lama fermentasi 18 jam (T1), sedangkan nilai total asam tertinggi terdapat pada perlakuan lama fermentasi 22 jam (T3) yang tidak berbeda nyata dengan perlakuan lama fermentasi 20 jam (T2), 24 jam (T4), 26 jam (T5).

Gambar 3 menunjukkan bahwa selama proses fermentasi fermented rice drink relatif terjadi peningkatan total asam seiring semakin lama fermentasi. Peningkatan total asam terjadi pada lama fermentasi 18 - 22 jam, dimana total asam meningkat dari $1,23 \%$ menjadi $1,71 \%$.

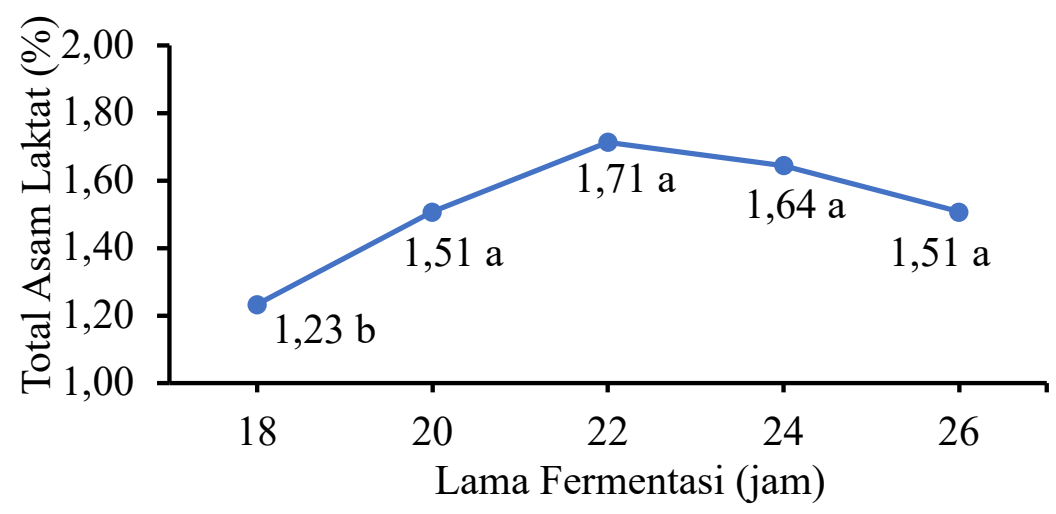

Gambar 3. Perubahan total asam fermented rice drink selama fermentasi 
Hal tersebut diduga terjadi karena bakteri asam laktat melalui sistem metabolismenya memanfaatkan kandungan gula pada fermented rice drink sebagai sumber energi dan karbon yang kemudian menghasilkan asam laktat sebagai produk hasil metabolisme. Menurut Yunus et al. (2015) semakin lama fermentasi, maka total asam yang dihasilkan akan semakin tinggi. Hal ini dikarenakan seiring meningkatnya lama fermentasi, maka semakin banyak waktu yang tersedia bagi bakteri asam laktat untuk merombak nutrisi yang terkandung dalam substrat dan dapat memungkinkan terakumulasinya asam-asam organik seperti asam laktat dalam jumlah yang lebih banyak.

Berdasarkan Gambar 3, total asam pada lama fermentasi antara 22 - 26 jam cenderung mengalami penurunan. Hal tersebut terjadi diduga karena pertumbuhan sel bakteri telah memasuki fase stasioner, dimana menurut Suharyono et al. (2012) selama fase stasioner terjadi penumpukan asam laktat sehingga dapat mengaktifkan enzim-enzim yang memetabolisir asam laktat lebih lanjut menjadi asamasam lemak rantai pendek seperti asetat, propionat, dan butirat. Menurut Schlegel (1994) asam laktat yang terbentuk pada proses fermentasi sebagian besar diubah menjadi asam propionat, dimana reduksi asam laktat menjadi asam propionat terjadi melalui alur metil malonil-KoA. Menurut Setiarto et al. (2017) ketika nutrisi media sudah sangat berkurang, maka bakteri asam laktat akan menggunakan asam-asam lemak yang terdapat pada media sebagai sumber energi untuk pertumbuhannya melalui jalur metabolisme $\beta$-oksidasi. Degradasi asam lemak yang terjadi melalui siklus $\beta$-oksidasi menghasilkan asetil- koenzim A (CoA), yang selanjutnya dimetabolisme untuk memperoleh energi dan prekursor biosintesis seluler (Diaz et al., 2017).

\section{Derajat Keasaman (pH)}

Hasil sidik ragam menunjukkan bahwa perlakuan lama fermentasi berpengaruh nyata $(\mathrm{P}<0,05)$ terhadap $\mathrm{pH}$ fermented rice drink. Gambar 4 menunjukkan bahwa nilai $\mathrm{pH}$ fermented rice drink berkisar antara 3,99 - 4,07. Nilai $\mathrm{pH}$ tertinggi terdapat pada perlakuan lama fermentasi 18 jam (T1), sedangkan nilai $\mathrm{pH}$ terendah terdapat pada perlakuan lama fermentasi 22 jam (T3) yang tidak berbeda nyata dengan perlakuan lama fermentasi 20 jam (T2), 24 jam (T4), 26 jam (T5). Gambar 4 menunjukkan bahwa selama proses fermentasi fermented rice drink terjadi penurunan nilai $\mathrm{pH}$ seiring semakin lama fermentasi. Penurunan $\mathrm{pH}$ terjadi pada lama fermentasi antara 18 - 22 jam, dimana nilai $\mathrm{pH}$ menurun dari 4,07 menjadi 3,99. Penurunan nilai $\mathrm{pH}$ tersebut merupakan akibat dari terakumulasinya asam laktat hasil metabolisme BAL selama proses fermentasi berlangsung, sehingga nilai $\mathrm{pH}$ akan cenderung semakin menurun seiring meningkatnya lama fermentasi.

Berdasarkan Gambar 4, pada fermentasi 22 26 jam terjadi peningkatan nilai $\mathrm{pH}$ yang relatif kecil. Menurut Suharyono et al. (2012) semakin lama fermentasi BAL maka semakin memicu terbentuknya asam-asam lemah seperti asam asetat, propionat, dan butirat yang merupakan hasil hidrolisis asam laktat. Nilai pKa asam asetat, asam propionat, dan asam butirat relatif hampir sama yaitu masing-masing 4,76 untuk asam asetat, 4,82 untuk asam propionat, dan 4,87 untuk asam butirat, 
sedangkan asam laktat bersifat sedikit lebih kuat dengan nilai pKa 3,85 . Oleh karena terjadinya hidrolisis asam laktat menjadi asam asetat, asam propionat, dan asam butirat, sehingga menyebabkan peningkatan nilai $\mathrm{pH}$.

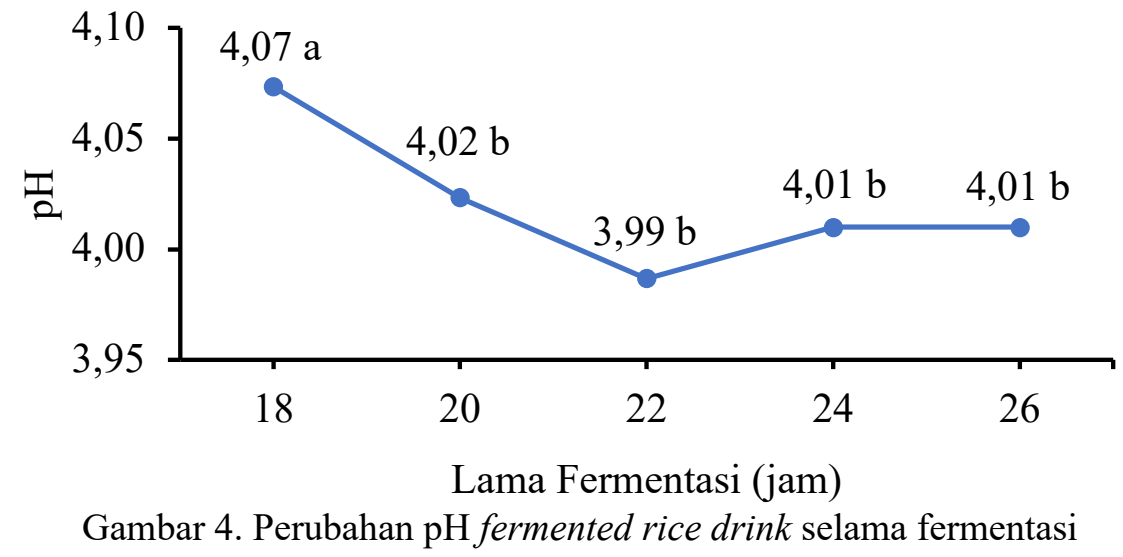

\section{Evaluasi Sensoris}

Evaluasi sifat sensoris fermented rice drink dilakukan dengan uji hedonik terhadap warna, aroma, rasa dan penerimaan keseluruhan serta uji skoring terhadap rasa manis dan rasa asam. Nilai rata-rata uji hedonik terhadap warna, aroma, rasa dan penerimaan keseluruhan fermented rice drink dapat dilihat pada Tabel 1, sedangkan nilai rata-rata uji skoring terhadap rasa manis dan rasa asam dapat dilihat pada pada Tabel 2.

\section{Warna}

Hasil sidik ragam menunjukkan bahwa perlakuan lama fermentasi tidak berpengaruh nyata $(\mathrm{P}>0,05)$ terhadap nilai kesukaan warna fermented rice drink. Tabel 8 menunjukkan bahwa nilai kesukaan warna fermented rice drink berkisar antara 5,53 - 5,80 dengan kriteria suka. Hal tersebut menunjukkan bahwa keseluruhan panelis memiliki tingkat kesukaan yang sama terhadap warna fermented rice drink.

\section{Aroma}

Hasil sidik ragam menunjukkan bahwa perlakuan lama fermentasi tidak berpengaruh nyata $(\mathrm{P}>0,05)$ terhadap nilai kesukaan aroma fermented rice drink. Tabel 8 menunjukkan bahwa nilai kesukaan aroma fermented rice drink berkisar antara 4,53 - 5,20 dengan kriteria agak suka hingga suka. Panelis beranggapan bahwa fermented rice drink pada semua perlakuan lama fermentasi memiliki aroma khas seperti tape beras.

\section{Rasa}

Hasil sidik ragam menunjukkan bahwa perlakuan lama fermentasi tidak berpengaruh nyata $(\mathrm{P}>0,05)$ terhadap nilai kesukaan rasa fermented rice drink. Tabel 8 menunjukkan bahwa nilai kesukaan rasa fermented rice drink berkisar antara 5,33 - 5,73 dengan kriteria agak suka hingga suka. Panelis beranggapan bahwa fermented rice drink pada semua perlakuan lama fermentasi memiliki rasa yang dominan manis. 
Tabel 1. Nilai rata-rata hedonik warna, aroma, dan penerimaan keseluruhan fermented rice drink dengan perlakuan lama fermentasi.

\begin{tabular}{ccccc}
\hline $\begin{array}{c}\text { Lama Fermentasi } \\
\text { (jam) }\end{array}$ & Warna & Aroma & Rasa & $\begin{array}{c}\text { Penerimaan } \\
\text { Keseluruhan }\end{array}$ \\
\hline T1 (18) & $5,53 \mathrm{a}$ & $4,93 \mathrm{a}$ & $5,73 \mathrm{a}$ & $5,73 \mathrm{a}$ \\
T2 $(20)$ & $5,80 \mathrm{a}$ & $5,20 \mathrm{a}$ & $5,60 \mathrm{a}$ & $5,93 \mathrm{a}$ \\
T3 $(22)$ & $5,60 \mathrm{a}$ & $5,07 \mathrm{a}$ & $5,53 \mathrm{a}$ & $5,80 \mathrm{a}$ \\
T4 $(24)$ & $5,67 \mathrm{a}$ & $4,53 \mathrm{a}$ & $5,60 \mathrm{a}$ & $5,40 \mathrm{a}$ \\
T5 $(26)$ & $5,67 \mathrm{a}$ & $4,73 \mathrm{a}$ & $5,33 \mathrm{a}$ & $5,60 \mathrm{a}$ \\
\hline
\end{tabular}

Keterangan: Huruf yang sama dibelakang nilai rata-rata pada kolom yang sama menunjukkan perlakuan berbeda tidak nyata $(\mathrm{P}>0,05)$. Kriteria Hedonik $(1=$ Sangat Tidak Suka; $2=$ Tidak Suka; 3 = Agak Tidak Suka; 4 = Biasa; 5 = Agak Suka; 6 = Suka; 7 = Sangat Suka).

Tabel 2. Nilai rata-rata hedonik rasa, skor rasa manis dan skor rasa asam fermented rice drink dengan perlakuan lama fermentasi.

\begin{tabular}{ccc}
\hline Lama Fermentasi (jam) & Skor Rasa Manis & Skor Rasa Asam \\
\hline T1 (18) & $1,80 \mathrm{a}$ & $1,73 \mathrm{~b}$ \\
T2 (20) & $2,07 \mathrm{a}$ & $2,00 \mathrm{~b}$ \\
T3 (22) & $2,07 \mathrm{a}$ & $1,93 \mathrm{~b}$ \\
T4 (24) & $2,13 \mathrm{a}$ & $2,53 \mathrm{a}$ \\
T5 (26) & $2,20 \mathrm{a}$ & $2,47 \mathrm{a}$ \\
\hline
\end{tabular}

Keterangan: Huruf yang sama dibelakang nilai rata-rata pada kolom yang sama menunjukkan perlakuan berbeda tidak nyata $(\mathrm{P}>0,05)$. Kriteria Skoring Rasa Manis $(1=$ Sangat Manis; $2=$ Manis; 3 = Agak Manis; 4 $=$ Tidak Manis). Kriteria Skoring Rasa Asam (1 = Tidak Asam; 2 = Agak Asam; $3=$ Asam; $4=$ Sangat Asam)

Hasil sidik ragam menunjukkan bahwa perlakuan lama fermentasi tidak berpengaruh nyata $(\mathrm{P}>0,05)$ terhadap skor rasa manis fermented rice drink. Tabel 8 menunjukkan bahwa skor rasa manis fermented rice drink berkisar antara 1,80 - 2,20 dengan nilai kriteria mutu terhadap rasa adalah manis. Hasil sidik ragam menunjukkan bahwa perlakuan lama fermentasi berpengaruh nyata $(\mathrm{P}<0,05)$ terhadap skor rasa asam fermented rice drink. Tabel 8 menunjukkan bahwa skor rasa asam fermented rice drink berkisar antara 1,73 - 2,53 dengan nilai kriteria mutu terhadap rasa adalah agak asam hingga asam.

\section{Penerimaan Keseluruhan}

Hasil sidik ragam menunjukkan bahwa perlakuan lama fermentasi tidak berpengaruh nyata
$(\mathrm{P}>0,05)$ terhadap nilai penerimaan keseluruhan fermented rice drink. Tabel 1 menunjukkan bahwa nilai penerimaan keseluruhan fermented rice drink berkisar antara 5,40 - 5,93. Nilai penerimaan keseluruhan terendah terdapat pada perlakuan lama fermentasi 24 jam (T4) dengan kriteria agak suka, sedangkan nilai penerimaan keseluruhan tertinggi terdapat pada perlakuan lama fermentasi 20 jam (T2) dengan kriteria suka. Berdasarkan penerimaan keseluruhan, fermented rice drink pada semua perlakuan lama fermentasi dapat diterima dengan baik oleh panelis. 


\section{KESIMPULAN DAN SARAN}

\section{Kesimpulan}

1. Lama fermentasi berpengaruh nyata terhadap total BAL, total gula, total asam, $\mathrm{pH}$, dan rasa asam fermented rice drink, sedangkan tidak berpengaruh nyata terhadap penerimaan warna, aroma, rasa, penerimaan keseluruhan, serta rasa manis fermented rice drink.

2. Lama fermentasi 22 jam menghasilkan fermented rice drink dengan karakteristik terbaik, dengan kriteria total BAL 13,26 Log CFU/ml; total gula $22,35 \%$; total asam $1,71 \%$; $\mathrm{pH} 3,99$; warna disukai; rasa manis dan agak asam disukai; aroma agak disukai, dan penerimaan keseluruhan disukai.

\section{Saran}

Berdasarkan hasil penelitian di atas disarankan untuk:

1. Untuk membuat fermented rice drink dengan karakteristik terbaik dapat dilakukan dengan perlakuan lama fermentasi 22 jam.

2. Untuk melakukan penelitian lebih lanjut mengenai umur simpan fermented rice drink dengan perlakuan lama fermentasi 22 jam.

\section{DAFTAR PUSTAKA}

Afrianti, H. 2013. Teknologi Pengawetan Pangan. Alfabeta, Bandung.

Andarwulan, N., F. Kusnandar, dan D. Herawati. 2011. Analisis Pangan. Dian Rakyat, Jakarta.

Buckle, K.A., R.A. Edwards, G.H. Fleet, dan M. Wootton. 1985. Ilmu Pangan. Penerjemah Hari Purnomo. Penerbit Universitas Indonesia, Jakarta.

Bouton, P.E. dan P.V. Harris. 1972. All About Yoghurt. Prentice Hall, Inc., Englewood Cliffs, New Jersey.

Diaz, L.J., A. Caballero, and A. Segura. 2017. Pathways for the Degradation of Fatty Acids in
Bacteria. Springer International Publishing, Spain.

Ding, W.K. dan N.P. Shah. 2008. Survival of free and microencapsulated probiotic bacteria in orange and apple juices. International Food Journal 15 (2): 219-232.

Fardiaz. 1993. Perhitungan total populasi bal pada yoghurt. E-journal :7-8.

Gomez dan Gomez. 1995. Review of the progress of dairy science: genetics of lactic acid bacteria. Journal of Dairy Review 48: 363-376.

Koesoemawardani D., S. Rizal, M. Tauhid. 2013. Perubahan sifat mikrobiologi dan kimiawi rusip selama fermentasi. Agritech 33(3): 265-272. Jurusan Teknologi Hasil Pertanian Fakultas Pertanian, Universitas Lampung.

Mardalena. 2016. Fase pertumbuhan isolat bakteri asam laktat (BAL) tempoyak asal jambi yang disimpan pada suhu kamar. Jurnal Sain Peternakan Indonesia 11(1): 58-66. Fakultas Peternakan Universitas Jambi.

Nout, R. 2007. The colonizing fungus as a food provider. Food Mycology. A Multifaceted Approach to Fungi and Food. hal: 335-352.

Purwandhani, S. N., E. S. Rahayu, M. Suladra. Efektivitas suplementasi agensia probiotik Lactobacillus acidophilus SNP-2 pada pembuatan tape ketan dan brem. Agritech 28(4): 180-185. Universitas Widya Mataram, Yogyakarta.

Ruck. 1963. Hot-loop test for the determination of carbon dioxide production from glucose by lactid acid bakteria. Appl. Environ Microbial 6(36): 990-991.

Schlegel, H.G. 1994. Mikrobiologi Umum. Edisi Keenam. Gadjah Mada University Press, Yogyakarta.

Setiarto, B.H., N. Widhyastuti, N.A. Rikmawati. 2017. Optimasi konsentrasi fruktooligosakarida untuk meningkatkan pertumbuhan bakteri asam laktat starter yoghurt. Jurnal Veteriner 18(3): 428-440.

Shah, N.P. 2007. Functional cultures and health benefits.Int. Dairy J. (17): 1262-1277.

Soekarto, S.T. 1985. Penelitian Organoleptik Untuk Industri Pangan dan Hasil Pertanian. Bharata Karya Aksara. Jakarta.

Suharyono, S. Rizal, F. Nurainy, M. Kurniadi. 2012. Pertumbuhan L.casei pada berbagai lama fermentasi minuman sinbiotik dari ekstrak cincau hijau (Premna oblongifolia merr). Jurnal Teknologi Hasil Pertanian, 5(2): 117-128. 
Sujaya, I N., K.A. Nocianitri, Y. Ramona, D.M. Sukrama, M.A. Wirawan, dan N.N.D. Fatmawati. 2015. Lama kolonisasi Lactobacillus sp. F213 pada saluran pencernaan dalam upaya pengembangan probiotik untuk menurunkan kolesterol. Penelitian Strategis Nasional, (Laporan).

Suprihatin. 2010. Teknologi Fermentasi. UNESA University Press. Surabaya

Suryani, Y., A. B. Oktavia dan S. Umniyati. 2010. Isolasi dan karakterisasi bakteri asam laktat dari limbah kotoran ayam sebagai agensi probiotik dan enzim kolesterol reduktase. Biologi dan Pengembangan Profesi Pendidik Biologi. Biota. 12 (3): 177-185.

Susanti, I., W.K. Retno, dan I. Fatim. 2007. Uji sifat probiotik bakteri asam laktat sebagai kandidat bahan pangan fungsional. Jurnal Teknologi dan Industri Pangan, 18 (2): 91-93.

Wongkhalaung, C. dan M. Boonyaratanakornkit. 2000. Development of a yogurt-type product from saccharified rice. Kasetsart J. (Nat. Sci.) (34): $107-116$.

Yuliana, N. 2008. Kinetika pertumbuhan bakteri asam laktat isolat T5 yang berasal dari tempoyak. Jurnal Teknologi Industri dan Hasil Pertanian 13(2): 108-116.

Yunus Y., E. Zubaidah. 2015. Pengaruh konsentrasi sukrosa dan lama fermentasi terhadap viabilitas $\mathrm{L}$. casei selama penyimpanan beku velva pisang ambon. Jurnal Pangan dan Agroindustri 3(2): 303312. Universitas Brawijaya Malang. 